\title{
Verapamil-Sensitive and Less Sensitive Contractions in the Intestinal Smooth Muscie of the Guinea-Pig Taenia Caeci
}

\author{
Hideaki KARAKI and Minori MITSUI \\ Department of Veterinary Pharmacology. Faculty of Agriculture, \\ The University of Tokyo, Bunkyo-ku. Tokyo 113, Japan \\ Accepted December 16, 1987
}

\begin{abstract}
Effect of verapamil, a $\mathrm{Ca}^{2+}$ channel blocker, on the contractions in the intestinal smooth muscle of taenia isolated from guinea-pig caecum was examined. In normal medium, $10 \mathrm{mM}-80 \mathrm{mM} \mathrm{KCl}$ or $10^{-7} \mathrm{M}-10^{-5} \mathrm{M}$ carbachol induced a transient contraction followed by a sustained one. When the muscle strips were treated with a $\mathrm{Ca}^{2+}$-free solution for $2 \mathrm{~min}$, these stimulants failed to induce contraction except an initial transient contraction induced by $10^{-6} \mathrm{M}-10^{-5} \mathrm{M}$ carbachol. Cumulative application of verapamil during the sustained contraction induced muscle relaxation. Higher concentration of verapamil was needed to inhibit the sustained contraction induced by $10 \mathrm{mM}$ or $20 \mathrm{mM} \mathrm{K}^{+}$than that induced by $40 \mathrm{mM}$ or $80 \mathrm{mM}$ $\mathrm{K}^{+}$. Similarly, the sensitivity to verapamil of the sustained contraction induced by $10^{-7} \mathrm{M}$ carbachol was lower than that induced by $10^{-6} \mathrm{M}$ or $10^{-5} \mathrm{M}$ carbachol. In the presence of verapamil, addition of either high $\mathrm{K}^{+}$or carbachol induced an initial transient contraction, although the sustained contraction was strongly inhibited. These results suggest that high $\mathrm{K}^{+}$and carbachol activate two types of $\mathrm{Ca}^{2+}$ channels: lower concentrations of the stimulants open the channel which is less sensitive to verapamil, and higher concentrations open the channel which is more sensitive to verapamil.
\end{abstract}

It has become recognized that a larger portion of the smooth muscle contraction is attributable to $\mathrm{Ca}^{2+}$ influx through $\mathrm{Ca}^{2+}$ channels and that $\mathrm{Ca}^{2+}$ channel blockers such as verapamil inhibit the smooth muscle contraction by inhibiting $\mathrm{Ca}^{2+}$ channels $(1-3)$. In the intestinal smooth muscle of taenia isolated from guinea-pig caecum, contractions induced by high $\mathrm{K}^{+}$-depolarization or by receptor agonists are composed of initial transient contraction followed by a sustained contraction. As for the mechanisms for these contractions, Urakawa and Holland (4) proposed that the transient contraction is due to release of celIular $\mathrm{Ca}^{2+}$, whereas the sustained contraction is due to $\mathrm{Ca}^{2+}$ influx. However, Imai and Takeda (5) showed that both of these contractions are dependent on the existence of external $\mathrm{Ca}^{2+}$ and suggested that both of these contractions are due to $\mathrm{Ca}^{2+}$ influx. Recently, it has been shown that although verapamil strongly inhibits the sustained con- traction, it has relatively weak inhibitory effect on the transient contraction $(1,6)$. In the present experiments, we further examined the effect of verapamil on the contractions in the taenia in order to clarify the mechanisms of these contractions in the intestinal smooth muscle of taenia. A part of the result has been briefly reported (7).

\section{Materials and Methods}

Male white guinea-pigs, weighing about $300 \mathrm{~g}$. were killed by a blow on the neck and bled. Strips of taenia were removed from the caecum and cut into small pieces, $5-10 \mathrm{~mm}$ in length.

The normal physiological salt solution (PSS) contained (mM): $\mathrm{NaCl}, 136.9 ; \mathrm{KCl}$, 5.4; glucose, 5.5: $\mathrm{NaHCO}_{3}, 23.8 ; \mathrm{CaCl}_{2}, 1.5$; $\mathrm{MgCl}_{2}, 1.0$; and ethylenediamine tetraacetic acid (EDTA), 0.01. $\mathrm{Ca}^{2+}$-free PSS was made by omitting $\mathrm{CaCl}_{2}$ and adding $0.5 \mathrm{mM}$ ethyleneglycol bis(beta-aminoethylether)- 


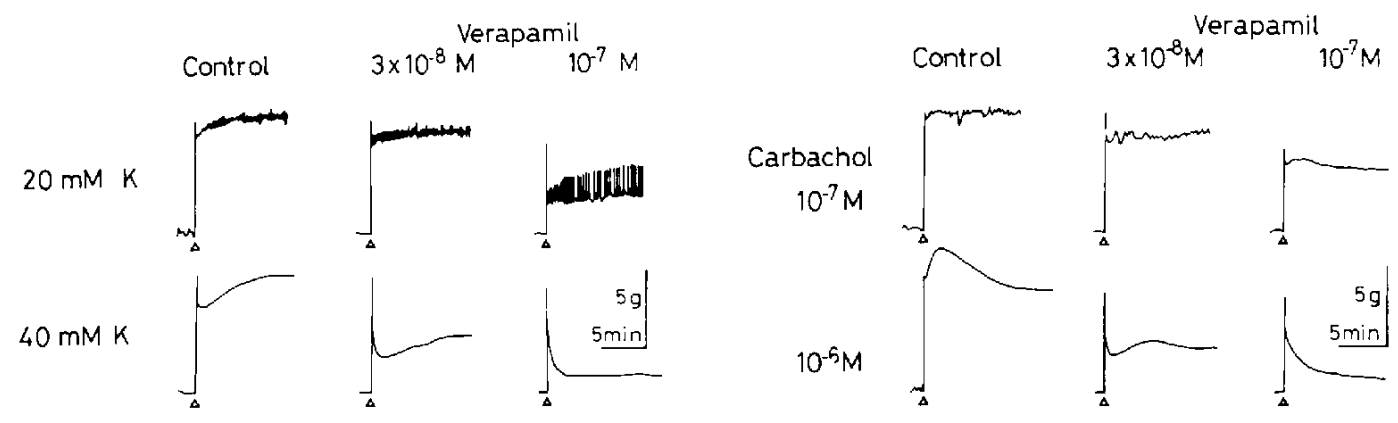

Fig. 1. Contractions induced by high $\mathrm{K}^{+}$(left) and carbachol (right) in the absence and in the presence of verapamil. Stimulant was added at the triangle. Verapamil was added $10 \mathrm{~min}$ before the addition of the stimulants. Scale indicates $5 \mathrm{~min}$ and $5 \mathrm{~g}$ tension. Traced from typical experimental data.

$N, N, N^{\prime}, N^{\prime}$-tetraacetic acid (EGTA) to the PSS. High $\mathrm{K}^{+}$solution was made by adding 10 $\mathrm{mM}-80 \mathrm{mM} \mathrm{KCl}$ to the PSS. These solutions were aerated with a mixture of $95 \% \mathrm{O}_{2}$ and $5 \% \mathrm{CO}_{2}$ at $37^{\circ} \mathrm{C}(\mathrm{pH} \mathrm{7.4)}$.

Muscle tension was recorded isometrically with a force-displacement transducer connected to a polygraph (Nihon Kohden). Passive tension of $0.2 \mathrm{~g}$ was initially applied, and the tissue was allowed to equilibrate for $60 \mathrm{~min}$ before starting the experimental period. Verapamil was cumulatively applied when the contractile tension induced by stimulants reached a steady level. In some experiments, verapamil was added $10 \mathrm{~min}$ before the addition of the stimulants unless otherwise stated.

Results of the experiments were expressed as the mean \pm S.E.M. Values were considered to be significantly different when the $P$ value was less than 0.05 using Student's $t$-test.

$( \pm)$ Verapamil hydrochloride (Sigma), nicardipine hydrochloride (Sigma) and carbamyl choline chloride (carbachol, Sigma) were used.

\section{Results}

In the isolated taenia strips, high $\mathrm{K}^{+}$or carbachol induced a transient contraction which was followed by a sustained contraction. As shown in Fig. 1, the sustained contraction reached a steady level 5 to $10 \mathrm{~min}$ after the addition of the stimulants. Magnitudes of the transient and sustained contractions induced by $\mathrm{KCl}$ or carbachol are shown in Fig. 2. Concentration-dependent contractions were obtained when 10,20 and 40

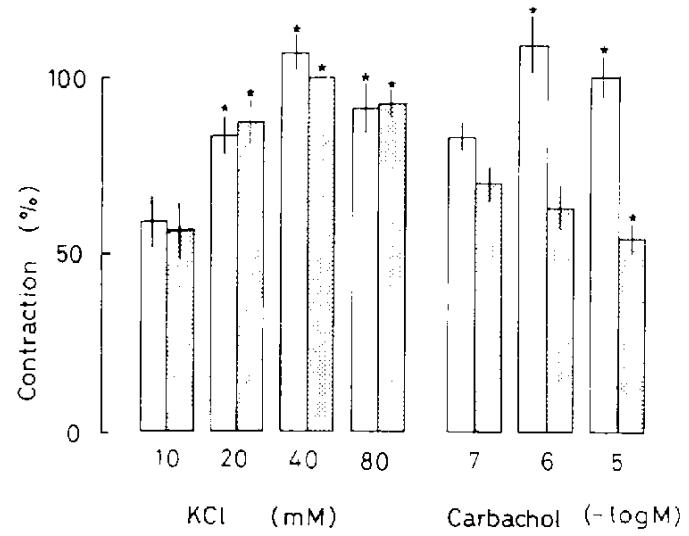

Fig. 2. Magnitude of contractions induced by $\mathrm{KCl}$ and carbachol. Open column represents initial transient contraction. Shaded column represents the steady level of the sustained contraction which was measured 5 to $10 \mathrm{~min}$ after the addition of stimulant. Magnitude of the sustained contraction induced by $40 \mathrm{mM} \mathrm{KCl}$ was taken as $100 \%$. Values of the mean \pm S.E.M. of 8 to 14 experimeı,ts are shown. *: Significantly different $(P<0.05)$ from the corresponding value obtained in the presence of $10 \mathrm{mM} \mathrm{KCl}$ (left) or $10^{-7} \mathrm{M}$ carbachol (right).

$\mathrm{mM} \mathrm{KCl}$ were added. However, the contractions induced by $80 \mathrm{mM} \mathrm{KCl}$ were almost the same as or slightly smaller than those induced by $40 \mathrm{mM} \mathrm{KCl}$. Carbachol, $10^{-7} \mathrm{M}$, induced a transient contraction which was smaller than that induced by $10^{-6} \mathrm{M}$ or $10^{-5} \mathrm{M}$ carbachol, and a sustained contraction which was greater than that induced by $10^{-5} \mathrm{M}$ carbachol.

In order to know the $\mathrm{Ca}^{2+}$ dependency of these contractions, muscle strips were treated with a $\mathrm{Ca}^{2+}$-free solution for $2 \mathrm{~min}$, and then 
high $\mathrm{K}^{+}$or carbachol was added. Neither high $\mathrm{K}^{+}$nor carbachol induced contraction in the absence of $\mathrm{Ca}^{2+}$ except the initial transient contraction induced by higher concentrations $\left(10^{-6}-10^{-5} \mathrm{M}\right)$ of carbachol, as has been reported (8).

The inhibitory effect of verapamil added cumulatively during the sustained contraction induced by high $\mathrm{K}^{+}$or carbachol is shown in Fig. 3. It is demonstrated that verapamil inhibited the sustained contractions and that the sensitivity to verapamil was dependent on the concentration of stimulant. Sustained contraction induced by $20 \mathrm{mM} \mathrm{K}^{+}$was less sensitive than that induced by $40 \mathrm{mM} \mathrm{K}^{+}$. Similarly, sustained contraction induced by
$10^{-7} \mathrm{M}$ carbachol was less sensitive than that induced by $10^{-6}$ or $10^{-5} \mathrm{M}$ carbachol.

Effects of verapamil on transient and sustained contractions induced by high $\mathrm{K}^{+}$or carbachol are shown in Fig. 1. When added 10 min after the addition of verapamil, these stimulants induced a transient contraction followed by a sustained contraction, and the latter contraction was more strongly inhibited than the former. Magnitudes of the sustained contractions measured in the presence of verapamil are shown in Fig. 4. This figure again shows that the contraction induced by 10 or $20 \mathrm{mM} \mathrm{K}^{+}$was less sensitive to verapamil than that induced by 40 or $80 \mathrm{mM}$ $\mathrm{K}^{+}$, and that the contraction induced by $10^{-7}$
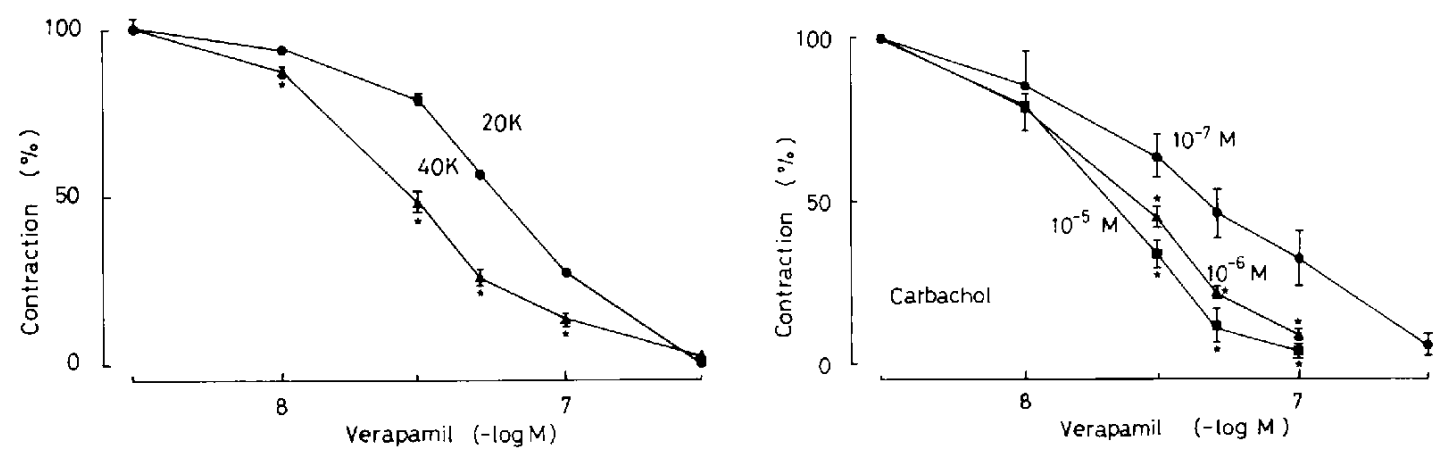

Fig. 3. Effect of verapamil on the sustained contractions induced by $20 \mathrm{mM} \mathrm{KCl}(20 \mathrm{~K}$ ) and $40 \mathrm{mM} \mathrm{KCl}$ (40 K) (left) and carbachol (right). Verapamil was cumulatively applied during the sustained contraction. Values of the mean \pm S.E.M. of 4 to 6 experiments are shown. *: Significantly different $(P<0.05)$ from the corresponding value obtained in the presence of $20 \mathrm{~m} \mathrm{M} \mathrm{KCl}$ (left) or $10^{-7} \mathrm{M}$ carbachol (right).
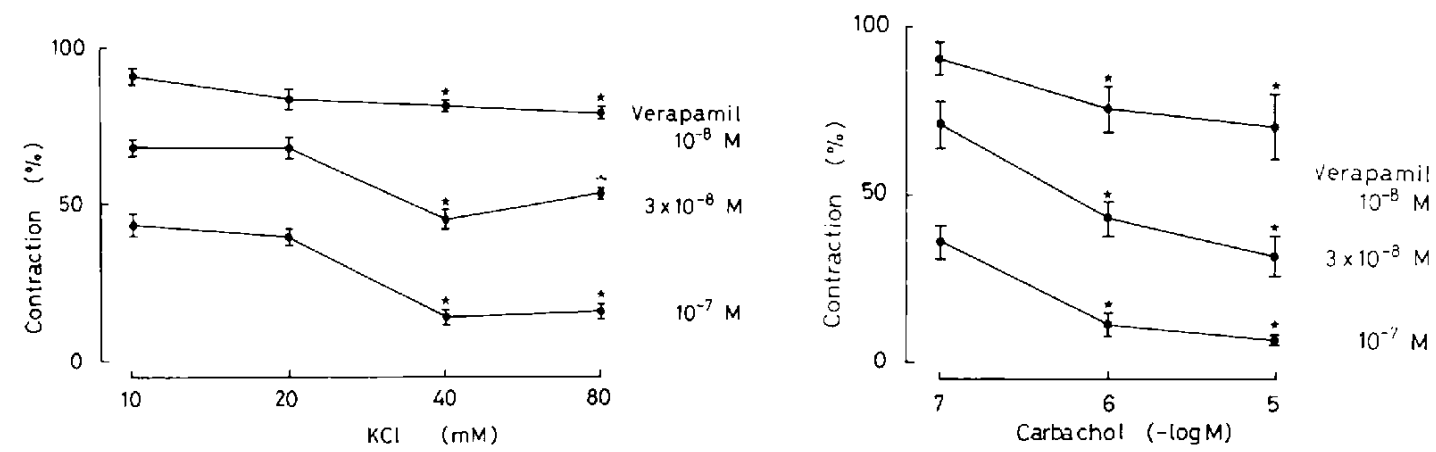

Fig. 4. Effects of verapamil on the sustained contractions induced by high $K^{+}$(left) and carbachol (right). Experiment was done as shown in Fig. 1, and the steady level of the sustained contraction in the absence of verapamil is taken as $100 \%$. Values of the mean \pm S.E.M. of 4 to 6 experiments are shown. *: Significantly different ( $P<0.05$ ) from the corresponding value obtained in the presence of $10 \mathrm{mM} \mathrm{KCl}$ (left) or $10^{-7} \mathrm{M}$ carbachol (right). 

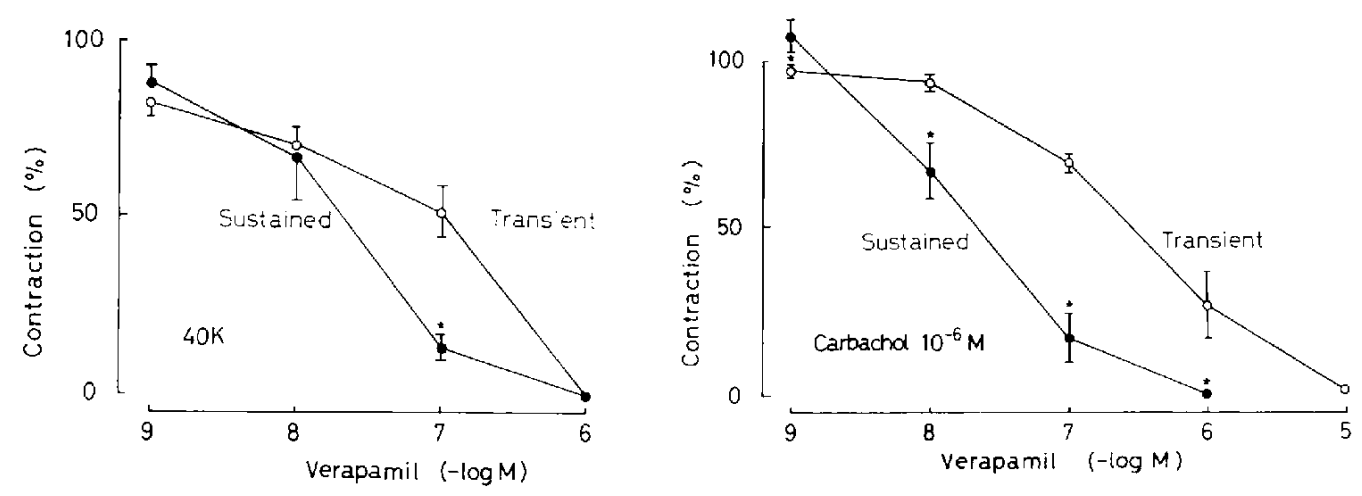

Fig. 5. Effects of verapamil on the transient and sustained contractions induced by $40 \mathrm{mM} \mathrm{KCl}(40 \mathrm{~K}$, left) and $10^{-6} \mathrm{M}$ carbachol (right). Experiment was done as shown in Fig. 1. and the level of the contractions in the absence of verapamil is taken as $100 \%$. Values of the mean \pm S.E.M. of 4 to 6 experiments are shown. *: Significaritly different $(P<0.05)$ from the transient contraction.

$M$ carbachol was less sensitive to verapamil than that induced by $10^{-6} \mathrm{M}$ or $10^{-5} \mathrm{M}$ carbachol.

Since $\mathrm{Ca}^{2+}$ channel blockers have a "usedependent" effect (9), the above experiment was repeated in which the effect of verapamil was expected to be maximally developed. In this experiment, verapamil was added during the $40 \mathrm{mM} \mathrm{K}^{+}$-induced contraction; and when the full inhibitory effect of verapamil was obtained, the muscle was washed with PSS containing the same concentration of verapamil, and then high $\mathrm{K}^{+}$or carbachol was added. Results of this experiments were almost the same as that in the above experiment, suggesting that the "use-dependent" nature of verapamil is not so clear in the guinea-pig taenia strips.

The concentration-inhibition curves for verapamil on the transient and sustained contractions, calculated from the experiments similar to that in Fig. 1 , are shown in Fig. 5 . It was shown that the transient contraction is less sensitive to verapamil than the sustained contraction induced by either $40 \mathrm{mM} \mathrm{KCl}$ or $10^{-6} \mathrm{M}$ carbachol. This figure also shows that the transient contraction induced by $10^{-6} \mathrm{M}$ carbachol was slightly less sensitive to verapamil than that induced by $40 \mathrm{mM} \mathrm{KCl}$.

The above experiments were repeated using a dihydropyridine $\mathrm{Ca}^{2+}$ channel blocker. nicardipine, instead of verapamil. This blocker, at the concentration of $3-5 \times 10^{-10} \mathrm{M}$. more strongly inhibited the sustained contraction than the transient contraction induced by 40 $\mathrm{mM} \mathrm{K}^{+}$or $10^{-6} \mathrm{M}$ carbachol. Further, $5 \times 10^{-10}$ $M$ nicardipine more strongly inhibited the sustained contraction induced by $10^{-5} \mathrm{M}$ carbachol (to $36.0 \pm 6.5 \%, n=4$ ) than that induced by $10^{-7} \mathrm{M}$ carbachol (to $64.1 \pm 5.9 \%$. $n=6, P<0.01$ ). In contrast to this, inhibitory effects of nicardipine on the sustained contractions induced by $20 \mathrm{mM} \mathrm{K}^{+}$and $80 \mathrm{mM}$ $\mathrm{K}^{+}$were not statistically significant.

\section{Discussion}

In the guinea-pig taenia strips, sustained contraction induced by $10^{-7} \mathrm{M}$ carbachol was more resistant to verapamil and nicardipine than those induced by $10^{-6}-10^{-5} \mathrm{M}$ carbachol. Similarly, sustained contraction induced by $10-20 \mathrm{mM} \mathrm{KCl}$ was more resistant to verapamil than that induced by $40-80 \mathrm{mM}$ $\mathrm{KCl}$, although the results with nicardipine were ambiguous. We did not expect such a result because opposite results have generally been obtained. For example, sustained contraction induced in vascular smooth muscle of rabbit aorta by $15 \mathrm{mM} \mathrm{KCl}$ was 10 -fold more sensitive than that induced by $140 \mathrm{mM}$ $\mathrm{KCl}$, and that induced by $10^{-8} \mathrm{M}$ norepinephrine was 10,000 -fold sensitive than that induced by $10^{-5} \mathrm{M}$ norepinephrine to a $\mathrm{Ca}^{2+}$ channel blocker, diltiazem (10). Similarly. sodium nitroprusside and forskolin more strongly inhibited the contraction induced by $10^{-8} \mathrm{M}$ norepinephrine than that induced by $10^{-6} \mathrm{M}$ norepinephrine in rat aorta (11). 
We also confirmed previous findings that the high $\mathrm{K}^{+}$- or carbachol-induced transient contractions in the taenia are more resistant to $\mathrm{Ca}^{2+}$ channel blockers than sustained contraction (1, 6, 8, 12). It has been shown that in the absence of external $\mathrm{Ca}^{2+}$, high concentrations of carbachol release $\mathrm{Ca}^{2+}$ from the cellular store to induce a transient contraction, and $\mathrm{Ca}^{2+}$ channel blockers do not inhibit this contraction (8, 13). However, contractions induced by $10-80 \mathrm{mM} \mathrm{K}^{+}$or $10^{-7} \mathrm{M}$ carbachol were rapidly inhibited in the absence of external $\mathrm{Ca}^{2+}$, although transient contractions induced by $10^{-6}-10^{-5} \mathrm{M}$ carbachol were more resistant to $\mathrm{Ca}^{2+}$ removal. These results support the suggestion (5) that both transient and sustained contractions induced by high $\mathrm{K}^{+}$and by $10^{-7} \mathrm{M}$ carbachol are triggered by $\mathrm{Ca}^{2+}$ influx. Only the transient contraction induced by $10^{-6}$ $10^{-5} \mathrm{M}$ carbachol may partly be due to a mechanism which is not triggered by $\mathrm{Ca}^{2+}$ influx, and this may be the reason why the transient contraction induced by $10^{-6} \mathrm{M}$ carbachol was more resistant to verapamil than that induced by high $\mathrm{K}^{+}$(Fig. 5).

In electrophysiological studies, it has been demonstrated that high $\mathrm{K}^{+}$and carbachol induce an increase in spike discharges. If the concentration of these stimulants are sufficiently high, the cell membrane is gradually depolarized to inhibit spike discharges. The concentration of $\mathrm{KCl}$ to inhibit spike discharges is approximately $40 \mathrm{mM}$ (14) and that of carbachol is approximately $10^{-6} \mathrm{M}$ (15). Thus, the initial transient contraction may be due to spike discharges (14-16). Further, sustained contractions induced by $10-20 \mathrm{mM} \mathrm{KCl}$ or $10^{-7} \mathrm{M}$ carbachol may also be due to spike discharges, whereas the sustained contraction induced by $40-80 \mathrm{mM}$ $\mathrm{KCl}$ or $10^{-6}-10^{-5} \mathrm{M}$ carbachol may be due to spike-free depolarization (14-16).

In smooth muscle, spike discharges are due to $\mathrm{Ca}^{2+}$ entry through $\mathrm{Ca}^{2+}$ channels. Further, membrane depolarization also opens $\mathrm{Ca}^{2+}$ channels (for review see 1 ). Recently, it has been shown that the membrane depolarization opens two types of $\mathrm{Ca}^{2+}$ channels: $T$ (for transient) channel. which is inactivated very rapidly at the polarized membrane potential, and $L$ (for long) channel, which is in- activated very slowly even at the depolarized membrane potential $(17,18)$. The $T$ channel is much less sensitive to $\mathrm{Ca}^{2+}$ Ichanne blockers than the $\mathrm{L}$ channel $(17,18)$. In cardiac muscle, there are similarly two types of $\mathrm{Ca}^{2+}$ channels (19), and Fabiato (20) proposed that $\mathrm{Ca}^{2+}$ current through the $T$ channel, but not the $L$ channel, releases $\mathrm{Ca}^{2+}$ from the storage site by activating the $\mathrm{Ca}^{2+}$. induced $\mathrm{Ca}^{2+}$ release mechanism. This hypothesis also explains the present results: Lower concentrations of the stimulants increase spike discharges possibly by activating T channels, trigger $\mathrm{Ca}^{2+}$ release and induce a transient contraction. Summation of such transient contractions may result in a sustained contraction which is less sensitive to $\mathrm{Ca}^{2+}$ channel blockers. In contrast to this. higher concentrations of the stimulants increase spike discharges to induce a transient contraction followed by a spike-free depolarization which opens the $\mathrm{Ca}^{2+}$ channel blocker-sensitive $L$ channel to induce a sustained contraction. Only higher concentrations of carbachol may release the $\mathrm{Ca}^{2+}$ store in the absence of triggering $\mathrm{Ca}^{2+}$ currents (8).

\section{References}

1 Bolton. T.B.: Mechanism of action of neurotransmitters and other substances on smooth muscle. Physiol. Rev. 59, 606-718 (1979)

2 Karaki, H. and Weiss, G.B.: Calcium channels in smooth muscle. Gastroenterology 87, 960-970 (1984)

3 Van Breemen, C., Aaronson, P. and Loutzenhiser, L.: $\mathrm{Na}-\mathrm{Ca}$ interactions in mammalian smooth muscle. Pharmacol. Rev. 30, 167-208 (1979)

4 Urakawa, N. and Holland, W.C.: $\mathrm{Ca}^{45}$ uptake and tissue calcium in $\mathrm{K}$-induced phasic and tonic contraction in taenia coli. Am. J. Physiol. 211, 1299-1304 (1966)

5 Imai, S. and Takeda, K.: Actions of calcium and certain multivalent cations on potassium contracture of guinea pig's taenia coli. J. Physiol. (Lond.) 190, 155-169 (1967)

6 Karaki, H., Nakagawa, H. and Urakawa, N.: Comparative effects of verapamil and sodium nitroprusside on contraction and ${ }^{46} \mathrm{Ca}$ uptake in the smooth muscle of rabbit aorta, rat aorta and guinea pig taenia coli. Br. J. Pharmacol. 81. 393-400 (1984)

7 Mitsui, M. and Karaki, H.: Differential inhibitory 
effects of verapamil on transient and sustained contractions in guinea-pig taenia caeci. Japan. J. Pharmacol. 43, Supp. 239P (1987)

8 Brading, A.F. and Sneddon, P.: Evidences for multiple sources of calcium for activation of the contractile mechanism of guinea-pig taenia coli on stimulation with carbachol. Br. J. Pharmacol. 70, 229-240 (1980)

9 Frank, G.B.: A pharmacological explanation of the use-dependency of the verapamil (and D$600)$ block of slow calcium channels. J. Pharmacol. Exp. Ther. 236, 505-511 (1985)

10 Van Breemen, C., Hwang, and Meisheri, K.D.: The mechanism of inhibitory action of ditiazem on vascular smooth muscie contractility. J. Pharmacol. Exp. Ther. 218, 459-463 (1981)

11 Lincoln, T.M. and Fisher-Simpson, V.: A comparison of the effects of forskolin and nitro. prusside on cyclic nucleotides and relaxation in the rat aorta. Eur. J. Pharmacol. 101, 17-27 (1983)

12 Morel, N., Hardy, J.P. and Godfraind, T.: Histamine-operated calcium channels in intestinal smooth muscle of the guinea-pig. Eur. J. Pharmacol. 135, 69-75 (1987)

13 Ohashi, H., Takewaki, T. and Okada, T.: Calcium and the contractile effect of carbachol in the depolarized guinea pig taenia caecum. Japan. J. Pharmacol. 24, 601-611 (1974)
14 Shimo, Y. and Holland, W.C.: Effects of potassium on membrane potential. spike discharge, and tension in taenia coli. Am. J. Physiol. 211, 1299-1304 (1966)

15 Bolton, T.B.: Action of acetylcholine on the smooth muscle membrane. In Smooth Muscle. Edited by Bülbring. E., Nrading. A.F., Jones, A.W. and Tomita. T., p. 199-217, Edward Arnold, London (1981)

16 Sigurdsson, S.B., Uvelius, B. and Johansson, B.: Relative contribution of superficially bound and extracellular calcium to activation of contraction in isolated rat portal vein. Acta Physiol. Scand. 95, 263-269 (1975)

17 Friedman, M.E., Suarez-Kurtz, G., Kaczorowski, G.J., Katz, G.M. and Reuben, J.P.: Two calcium currents in a smooth muscle cell line. Am. J. Physiol. 250, H699-H703 (1986)

18 Spedding, $\mathrm{M}$.: Three types of $\mathrm{Ca}^{2+}$ channel explain discrepancies. TIPS 8, 115-117 (1987)

19 Bean, B.P.: Two kinds of calcium channels in canine atrial cells. Differences in kinetics, selectivity, and pharmacology. J. Gen. Physiol. 86. 1-30 (1985)

20 Fabiato, A.: Simulated calcium current can both cause calcium loading and trigger calcium release from the sarcoplasmic reticulum of a skinned canine Purkinje cell. J. Hen. Physiol. $85,291-320(1985)$ 